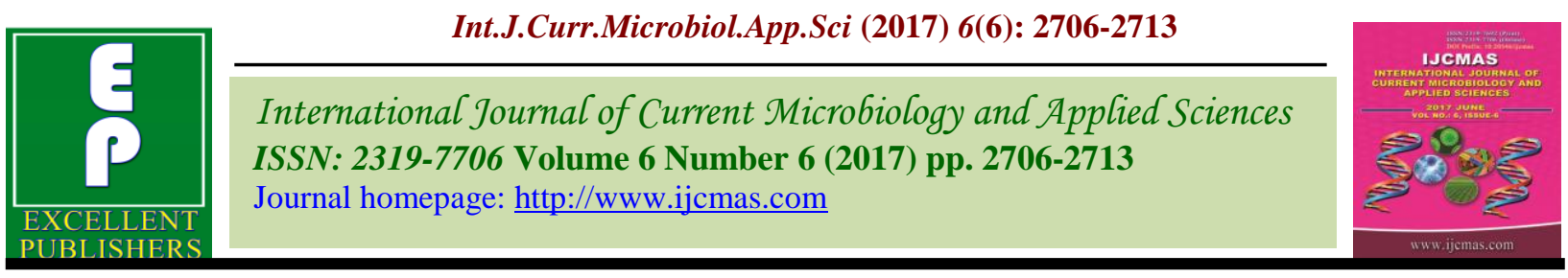

Original Research Article

https://doi.org/10.20546/ijcmas.2017.605.303

\title{
Antimicrobial Activity of Black Fruit Variant of Solanum nigrum L.
}

\author{
S. Shahiladevi* and M. Jegadeesan \\ Department of Environmental and Herbal Sciences, Tamil University, \\ Thanjavur - 613 005, Tamil Nadu, India \\ *Corresponding author
}

\begin{tabular}{|c|c|}
\hline & A B S T R A C T \\
\hline & \multirow{8}{*}{$\begin{array}{l}\text { Solanum nigrum L. generally known as black nightshade is one of the common } \\
\text { Indian medicinal plants, which belongs to family Solanaceae. All parts of the plant } \\
\text { i.e., leaf, stem, root, flower and fruits are used for the treatment of various } \\
\text { diseases. The members of this taxon differ from each other on the basis of some } \\
\text { important morphological characters like fruit colour, size of seeds, pollen grains } \\
\text { and stomata. For the present investigation, entire plant of black fruited variant of } \\
\text { Solanum nigrum was selected and antimicrobial activity was screened. The } \\
\text { antimicrobial activity of three different concentrations, } 25 \mu \mathrm{g} / \mathrm{ml}, 50 \mu \mathrm{g} / \mathrm{ml} \text { and } \\
100 \mu \mathrm{g} / \mathrm{ml} \text { of } 50 \% \text { of ethanol extract of Solanum nigrum (black fruited) was } \\
\text { screened against two Gram negative bacteria, Escherichia coli and Pseudomonas } \\
\text { aeruginosa, a Gram positive bacterium, Staphylococcus aureus and three species } \\
\text { of fungi i.e., Aspergillus niger, Aspergillus flavus and Candida albicans by well } \\
\text { and disc diffusion methods. Fifty percent ethanol extract of black fruit variant of } \\
\text { Solanum nigrum exhibited dose dependent significant inhibitory activities against } \\
\text { both bacterial and fungal strains at tested concentrations. }\end{array}$} \\
\hline Keywords & \\
\hline & \\
\hline Black fruited & \\
\hline $\begin{array}{l}\text { Black nightshade } \\
\text { Solanaceae } \\
\text { Solanum nigrum L. }\end{array}$ & \\
\hline Article Info & \\
\hline $\begin{array}{l}\text { Accepted: } \\
25 \text { May } 2017 \\
\text { Available Online: } \\
\text { 10 June } 2017\end{array}$ & \\
\hline & \\
\hline
\end{tabular}

\section{Introduction}

Infectious diseases are important health hazard all over the world, both in developing and developed countries. Antimicrobial drugs are currently used in medicinal practice for treating various diseases. A number of researchers nowadays are working seriously to find out substitute for antibiotics as they cause side effects on the functioning of different parts of the body and biological systems. There is a necessity from the scientific point of view, to establish a rational relationship between chemical, biological and therapeutic activities of folklore medicine (Levin, 1976; Gentry, 1993). Medicinal and aromatic plants and their essences are rich in antibacterial compounds which could provide an alternate way to combat bacterial diseases (Samy et al., 1998; Meera et al., 1999). A number of studies have been reported dealing with antimicrobial screening of extracts of medicinal plants (Malcom and Sotowora, 1969; Brantner and Grein, 1994; Perumalsamy and Ignacimuthu, 1997; Ramaswamy and Charles Manoharan, 2004). Plant derived drugs serve as a prototype to develop effective and less toxic medicines. In this regard, the plant, Solanum nigrum L. (black fruited) (Family - Solanaceae) is used for treating various human ailments 
traditionally. Hence it was selected and screened for its antimicrobial activity. The entire plant of this plant is considered to possess anti dysenteric, diuretic, anti-ulcer, anti-cancer, emollient and laxative properties. All parts of Solanum nigrum are medicinally important. Various medicinal properties of Solanum nigrum are described by Chopra et al., (1956) and Kritikar and Basu (1935).

The plant has been used as an emollient and analgesic to treat itch, burns and neuralgic pains, expectorant and laxative. The leaves are said to have sedative and healing properties, and are applied to cuts, ulcers, wounds, inflammations and skin diseases. The fruit or ripe berries are considered to be a cure for diabetes, fever, diarrhoea and eye disease. The young shoots are given in skin diseases and in psoriasis. The root bark is laxative, useful in diseases of ear, the eye and the nose, good for ulcers, burning of the throat and inflammation of the liver. The seeds are laxative, useful in giddiness, gonorrhea, thirst and inflammation. Therefore an attempt has been made to study the antibacterial activity of $50 \%$ ethanol i.e., extract of entire plant of Solanum nigrum (black fruited) was screened for certain pathogenic microorganisms and the results are reported.

\section{Materials and Methods}

\section{Collection and identification of plant materials}

The entire plant of Solanum nigrum L. (black fruited) was collected from Thirumalairayanpattinam, Karaikal region, Pondicherry Union Territory located at latitude $10^{\circ} 55^{\prime} \mathrm{N}$ and longitude $79^{\circ} 50^{\prime} \mathrm{E}$ at $\mathrm{m} \mathrm{MSL}$ during 2011 and collected plant was carefully examined and identified according to regional floras, (Gamble, 1957; Matthew, 1983).
Specimen was further confirmed with reference to herbarium sheets available in the Rapinat Herbarium, St. Joseph College, Thiruchirapalli and Botanical survey of India, Southern circle, Coimbatore. The herbarium number in BSI is "BSI/SRC/5/23/201213/Tech. 1480". The herbarium specimen was deposited at Tamil University Herbarium (TUH-300).

\section{Preparation of extracts}

The shade dried entire plant of Solanum nigrum L. variant black fruited was mechanically grounded to coarse powder and passed through an 80 mesh sieve. This powdered material was percolated in $50 \%$ ethanol for 24 hours. The obtained ethanol extract subjected to several dilutions $(25 \mu \mathrm{g} / \mathrm{ml}, 50 \mu \mathrm{g} / \mathrm{ml}$ and $100 \mu \mathrm{g} / \mathrm{ml})$.

\section{Preparation of microbial inoculums}

The young microbial inoculums/cultures were prepared. The Nutrient Broth (NB) and Potato Dextrose Broth (PDB) were prepared and poured into several tubes. Then these tubes were sterilized.

The pure microbial cultures were collected from National Committee for Clinical Laboratory Standards, Chandigarh and inoculated in the tubes by using inoculation needles or loops. These tubes were incubated at $37^{\circ} \mathrm{C}$ for $24-28$ hours for bacteria and at $27^{\circ} \mathrm{C}$ for $48-72$ hours for fungi. After incubation the cultures were used for the experiments.

\section{Preparation of nutrient agar medium}

The nutrient agar medium (1000 ml) was prepared and $\mathrm{pH}$ was adjusted to 6.8 using a $\mathrm{pH}$ meter by the addition of either acid (or) alkali. The medium was sterilized by using autoclave of $121^{\circ} \mathrm{C}$ for $15 \mathrm{lbs}$ pressure for 15 min and allowed to cool. 


\section{Preparation of potato dextrose agar medium}

The potatoes were peeled and weighed for about $200 \mathrm{~g}$. The tubers were chopped into small pieces with the help of sterile knife. The chopped potatoes were transferred into a conical flask containing about $100 \mathrm{ml}$ of distilled water. The content was boiled for 20 minutes.

The supernatant were decanted and filtered by muslin cloth and the filtrate was collected. 20 $\mathrm{g}$ of Dextrose and $15 \mathrm{~g}$ of Agar was transferred into the extract and shacked to dissolve the ingredients. The medium was made up to one litre by the addition of distilled water. The $\mathrm{pH}$ of the medium was adjusted to 5.6 by using $1 \mathrm{~N}$ hydrochloric acid or Sodium hydroxide drop wise. Finally the medium was poured into two conical flasks and cotton plugged and sterilized in pressure cooker for 20 minutes.

\section{Screening of antimicrobial activity}

\section{Dilution method}

Minimum Inhibitory Concentration (MIC) was carried out by agar dilution method (Mitscher et al., 1972). The $17 \mathrm{ml}$ of sterilized NA medium and PDA were poured into each sterile petri plates and allowed to solidify. The test bacterial and fungal strains were evenly spread over the appropriate media by using a sterile cotton swab.

\section{Positive control and negative control}

Standard antibiotic such as Kanamycin, tetracycline and Griseofulvin were used as positive control against bacteria and fungi respectively and ethanol was used as negative control.

\section{Determination of antimicrobial activity}

Well are made on the agar surface with 0.5 $\mathrm{cm}$ diameter by using a sterile stainless steel cork borer. The plant extract were injected into wells using a micro pipette at a dose of $25 \mu \mathrm{g} / \mathrm{ml}, 50 \mu \mathrm{g} / \mathrm{ml}$ and $100 \mu \mathrm{g} / \mathrm{ml}$. After that, these plates were incubated at $37^{\circ} \mathrm{C}$ for 24 48 hours for bacteria and at $27^{\circ} \mathrm{C}$ for $48-72$ hours for fungi.

After the incubation period, the results were observed and measure the diameter of inhibition zone around the each well.

\section{Results and Discussion}

The results of the antimicrobial activity of the $50 \%$ ethanol extract of entire plant of Solanum nigrum L. (black fruited) in three concentrations $(25 \mu \mathrm{g} / \mathrm{ml}, 50 \mu \mathrm{g} / \mathrm{ml}$ and 100 $\mu \mathrm{g} / \mathrm{ml})$ and zone of inhibition in millimeter $(\mathrm{mm})$ are given in Table 1 and Plate 1,2 and 3 , antibiotic sensitivity test on bacteria and fungi (positive control) given in Table 2 and 3 , Plate 2 and effect of solvent on microbesbacteria and fungi (negative control) (Table 4; Plate 3).

The presence of antimicrobial substances in higher plants is well established. Plants have provided a source of inspiration for novel drug compounds as plants derived medicines have made significant contribution towards human health.

The present investigation ensure that $50 \%$ ethanol extract of black fruited Solanum nigrum contain antimicrobial properties, which are used in different parts of country and other countries as valuable traditional medicine. 
Table.1 Antimicrobial activity of 50\% ethanol extract of Solanum nigrum L. Variant black fruited

\begin{tabular}{|l|l|l|l|l|}
\hline \multirow{2}{*}{ S. NO } & \multirow{2}{*}{$\begin{array}{l}\text { Name of the } \\
\text { microorganism }\end{array}$} & \multicolumn{3}{|l|}{$\begin{array}{l}\text { Ethanol extract in different concentration } \\
\text { (Zone of inhibition in mm) }\end{array}$} \\
\cline { 3 - 5 } & & $\mathbf{2 5} \boldsymbol{\mu g} / \mathbf{m l}$ & $\mathbf{5 0} \mathbf{\mu g} / \mathbf{m l}$ & $\mathbf{1 0 0} \boldsymbol{\mu g} / \mathbf{m l}$ \\
\hline & Bacterial cultures & 15 & 19 \\
\hline 1. & Pseudomonas aeruginosa & 14 & 14 & 15 \\
\hline 2. & Staphylococcus aureus & 11 & 12 & 13 \\
\hline 3. & Escherichia coli & 11 & 14 & 15 \\
\hline & Fungi cultures & 12 & 12 & 13 \\
\hline 1. & Aspergillus niger & 11 & 13 & 14 \\
\hline 2. & Aspergillus flavus & - & \multicolumn{5}{|l}{} \\
\hline 3. & Candida albicans &
\end{tabular}

Table.2 Antibiotic sensitivity test on bacteria (Positive control)

\begin{tabular}{|l|l|l|l|}
\hline \multirow{2}{*}{ S. No } & \multirow{2}{*}{ Name of the bacteria } & \multicolumn{2}{|l|}{ Standard antibiotics (Zone of inhibition in $\mathbf{~ m m}$ ) } \\
\cline { 3 - 4 } & & Kanamycin & Tetracycline \\
\hline 1. & Pseudomonas aeruginosa & 20 & 10 \\
\hline 2. & Staphylococcus aureus & 13 & 12 \\
\hline 3. & Escherichia coli & 19 & 11 \\
\hline
\end{tabular}

Table.3 Antibiotic sensitivity test on fungi (Positive control)

\begin{tabular}{|l|l|l|}
\hline \multirow{2}{*}{ S. No } & \multirow{2}{*}{ Name of the fungi } & Standard Antibiotics (Zone of inhibition in $\mathbf{~ m m}$ ) \\
\cline { 3 - 3 } & & Griseofulvin \\
\hline 1. & Aspergillus niger & 12 \\
\hline 2. & Aspergillus flavus & 13 \\
\hline 3. & Candida albicans & 12 \\
\hline
\end{tabular}

Table.4 Effect of solvent on tested microbes (Negative control)

\begin{tabular}{|l|l|l|}
\hline \multirow{2}{*}{ S. No } & \multirow{2}{*}{ Name of the organisms } & Zone of inhibition in $\mathbf{~ m m}$ \\
\cline { 3 - 3 } & & Ethanol \\
\hline 1. & Pseudomonas aeruginosa & - \\
\hline 2. & Staphylococcus aureus & - \\
\hline 3. & Escherichia coli & - \\
\hline 4. & Aspergillus niger & - \\
\hline 5. & Aspergillus flavus & - \\
\hline 6. & Candida albicans & - \\
\hline
\end{tabular}




\section{Plate.1}
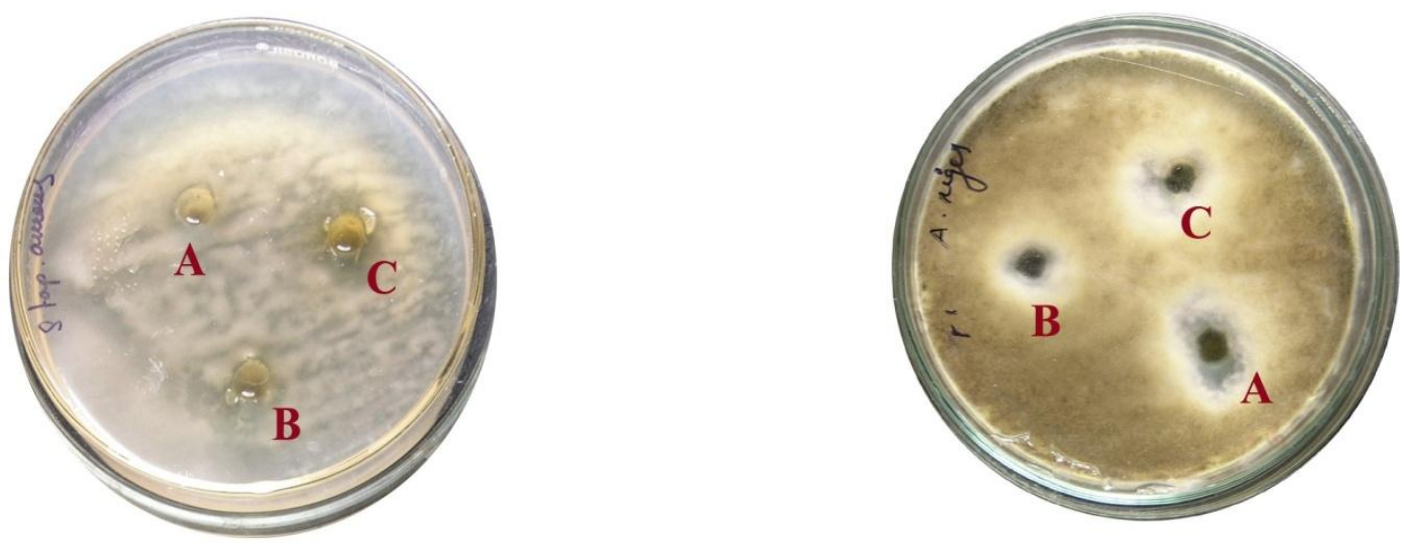

a) Pseudomonus aeruginosa

d) Aspergillus niger
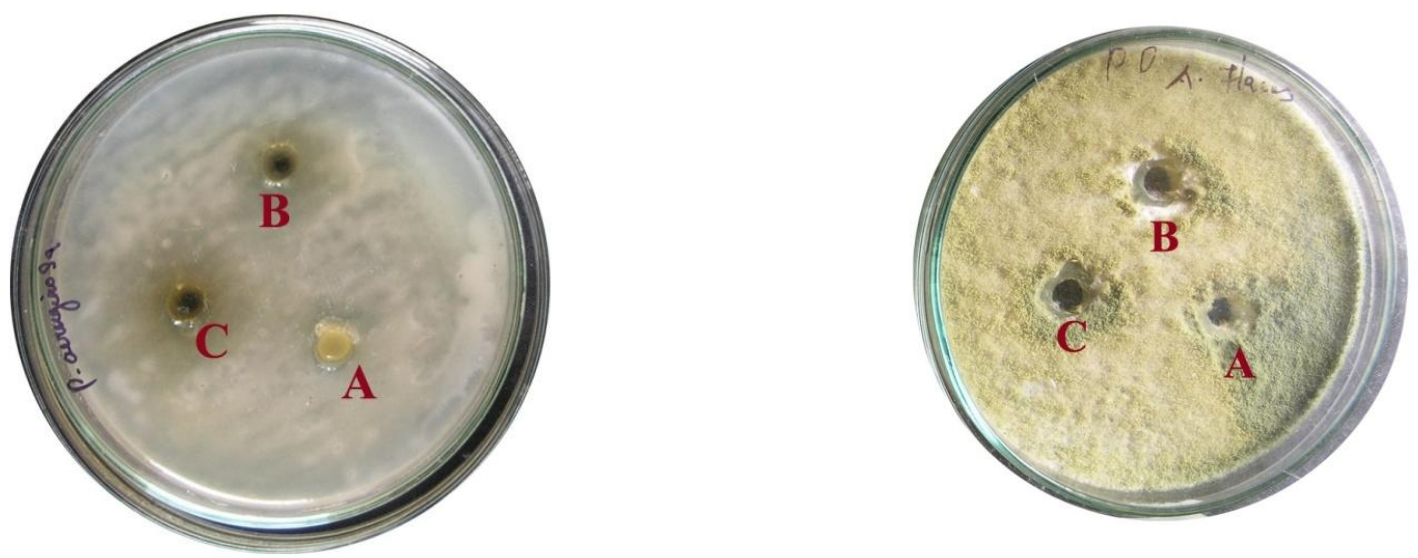

b) Staphylococcus aureus

e) Apergillus flavus
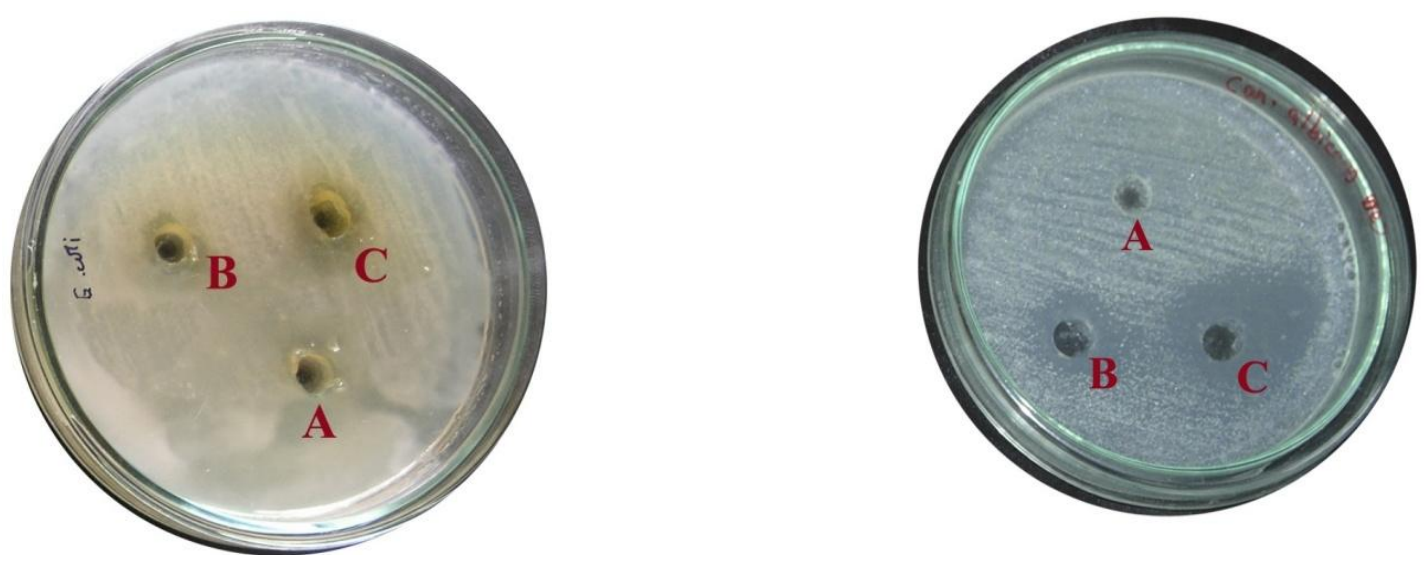

c) Escherichia coli

f) Candida albicans

\section{A-25 $\mu \mathrm{g} / \mathrm{ml} \quad$ B-50 $\mu \mathrm{g} / \mathrm{ml} \quad \mathrm{C}-100 \mu \mathrm{g} / \mathrm{ml}$}




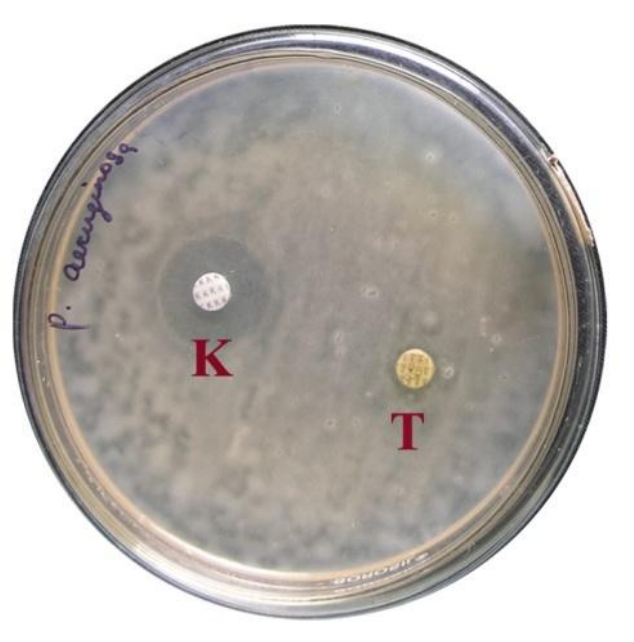

b) Pseudomonas aeruginosa

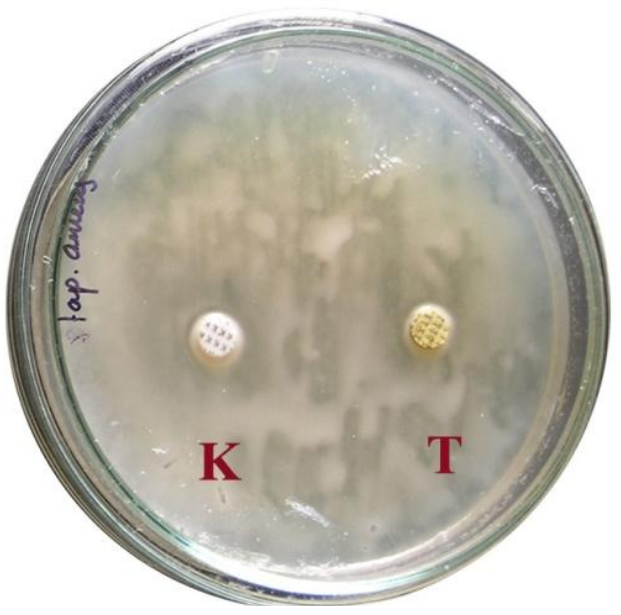

b) Staphylococcus aureus

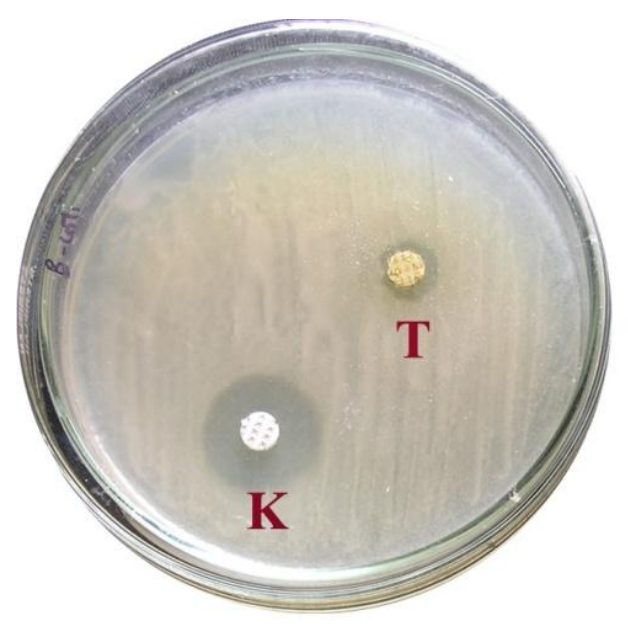

c) Escherichia coli

\section{Plate.2}

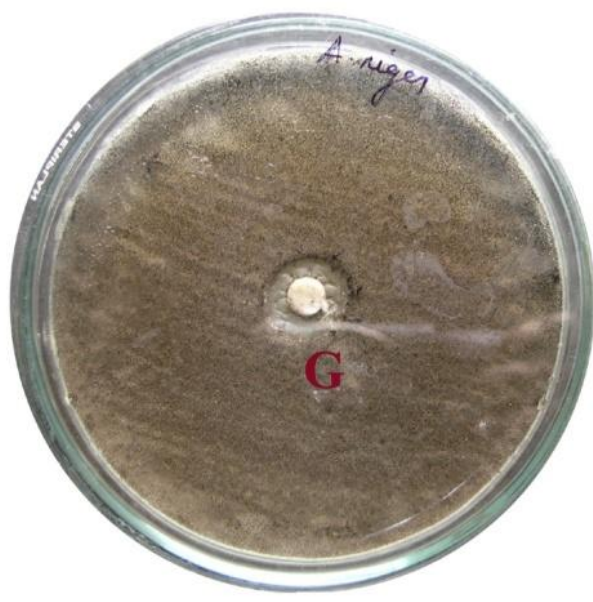

d) Aspergillus niger

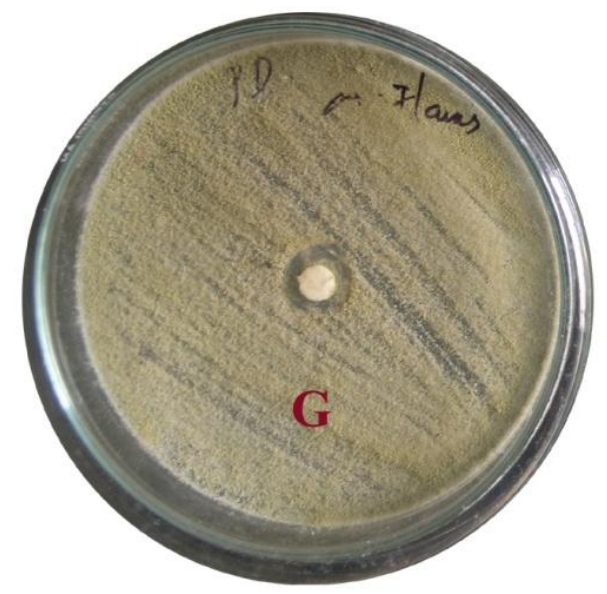

e) Apergillus flavus

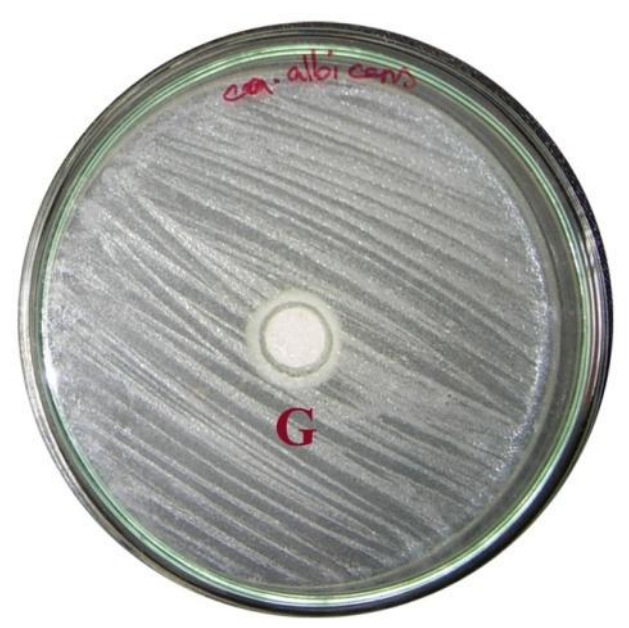

f) Candida albicans

\section{K-Kanamycin T-Tetracyclin}

\section{G-Grisofulvin}




\section{Plate.3}
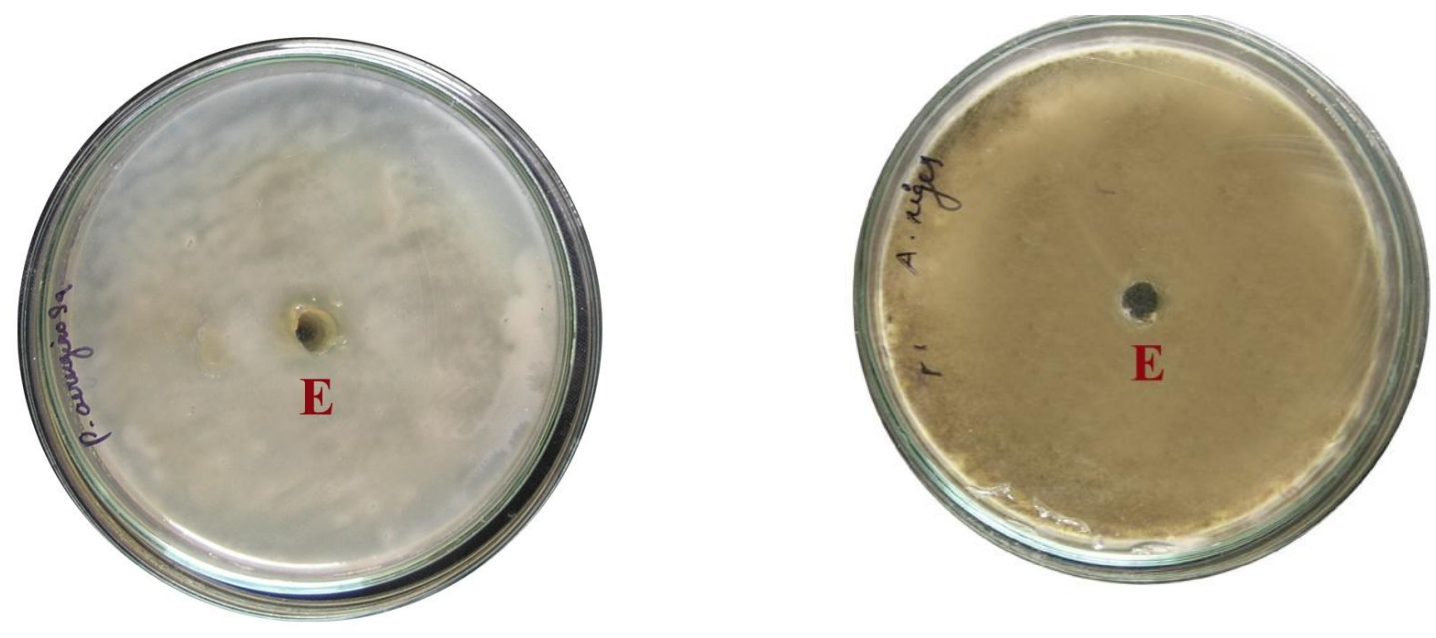

a) Pseudomonas aeruginosa

d) Aspergillus niger
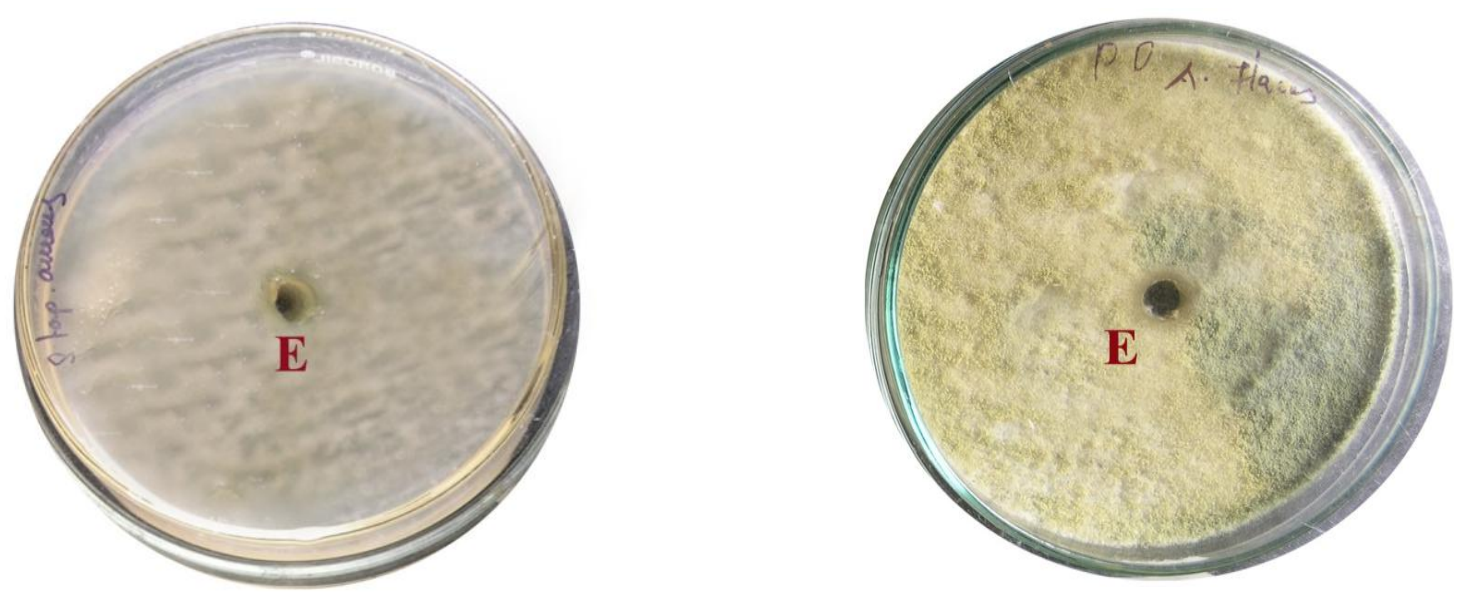

b) Staphylococcus aureus

e) Apergillus flavus
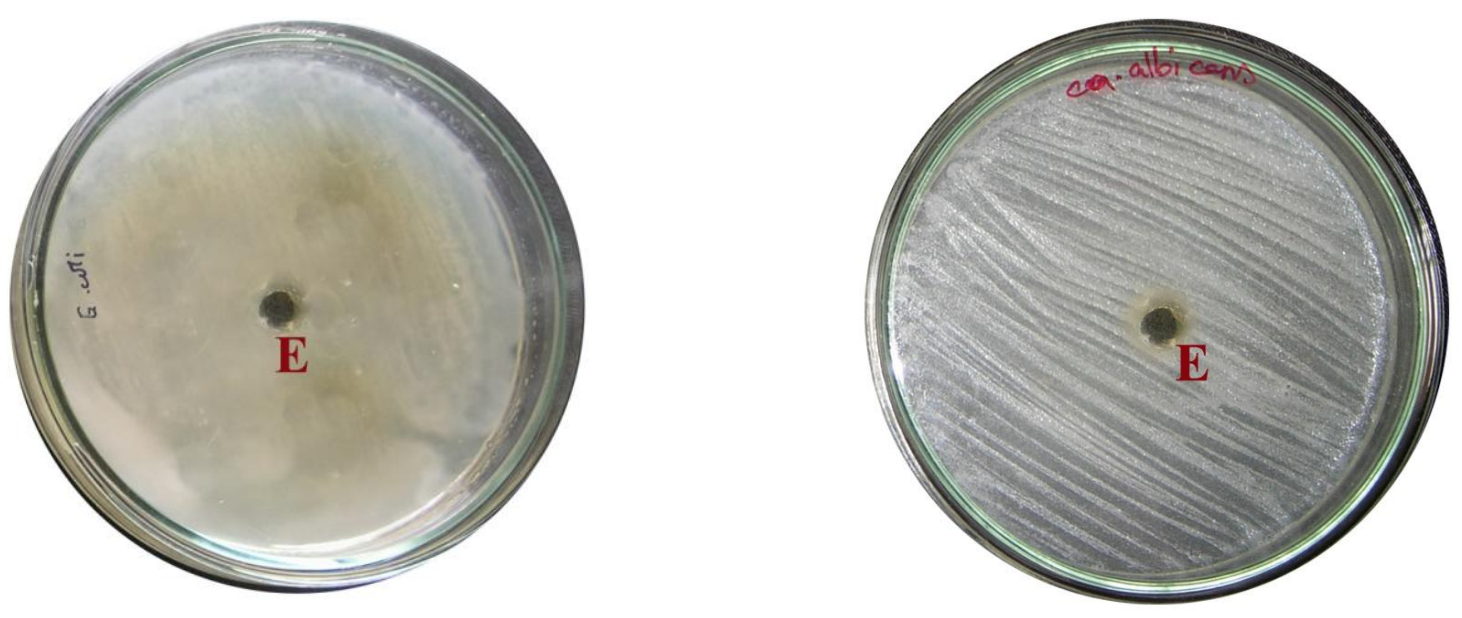

c) Escherichia coli

f) Candida albicans

\section{E - Ethanol}


Indigenous drugs have significant role in human health care management program and have been used since ancient time. Developments of herbal drugs against multidrug resistant microbial pathogens necessitate screening and selection of Indian medicinal plants. Solanum nigrum plant is a promising medicinal plant for development of MDR drug. In this work $50 \%$ ethanol entire plant extract of Solanum nigrum black fruited is found efficacious against both antibacterial and antifungal species.

\section{References}

Brantner, A. and Grein, E. 1994. Antibacterial activity of plant extracts used externally in traditional medicine. $J$. Ethnopharmacol., 44: 35-40.

Chopra, R.N., Nayar, S.L. and Chopra, I.C. 1956. Glossary of Indian Medicinal Plants. CSIR, New Delhi, India, 229.

Gamble, J.S. 1957. Flora of presidency of Madras. Vol.3, Botanical Survey of India, Calcutta, India, 816.

Gentry, A.H. 1993. Tropical forest biodiversity and the potential for new medicinal plants. In: Human medicinal agents from plants, American Chemical Society (ACS Symposium series 534), Washington, DC, 13-24.

Kirtikar, K.R. and Basu, B.D. 1935. Indian Medicinal Plants. L.M. Basu, Allahabad, III: 1765.
Levin, D.A. 1976. Nature Biotechnology, American Naturalist, 110: 261-284.

Malcom, S.A and Sotowora, E.A. 1969. Antimicrobial activity of selected Nigerian folk remedies and their constituent plants, J. Natural Products, 34(4): 512-517.

Matthew, K.M. 1983. The flora of Tamilnadu Carnatic, III, The Rapinat Herbarium, Tiruchirapalli, 1151.

Meera, P., Dora, P.A. and Samuel, J.K. 1999. Antibacterial effect of selected medicinal plants on the bacteria isolated from juices, Geobios, 26: 17-20.

Mitscher, L.A., Lev, R., Bathala, M.S., Wu, W., Beal, J.L. 1972. Antimicrobial agents from higher plants. Introduction, rational and methodology. Lioydia, 35: 157-166.

Perumalsamy, R. and Ignacimuthu, S. 1997. Antibacterial activity of some medicinal plants from eastern chats, South India, Solai Bull. Ethnopharmacol., 39-41.

Ramaswamy, S. and Charles Manoharan, A. 2004. Antibacterial effect of volatile components of selected medicinal plants against human pathogens, Asian $J r$. Microbial. Biotech. Env. Sci, 6(2): 209210.

Samy, R.P., Ignacimuthu, G. and Sen, A. 1998. Screening of 34 Indian medicinal plants for antibacterial properties. $J$. Ethnopharmacol., 62: 172-182.

\section{How to cite this article:}

Shahiladevi, S., and Jegadeesan, M. 2017. Antimicrobial Activity of Black Fruit Variant of Solanum nigrum L. C. Int.J.Curr.Microbiol.App.Sci. 6(6): 2706-2713. doi: https://doi.org/10.20546/ijcmas.2017.605.303 